\title{
CPEC in Pakistani Print Media: Transitivity Analysis of English Newspapers' Articles
}

\author{
Afsheen Ekhteyar ${ }^{1} *$ and Tariq Umrani ${ }^{2}$
}

\begin{abstract}
The purpose of the study is to scrutinize critically the ideological constructions and discursive features used in Pakistani print media representing economical phenomenon of CPEC. This research has elucidated the ideology through critical discourse analysis (CDA) of the leading English newspapers of a good repute: However, the similar news from the different newspapers as depicted in the various forms that are all ideologically disputed in this perspective including Daily Dawn and The News HE NEWS. These articles on CPEC, the most prevailing economic subject in Pakistan as published during the year 2016-17, have been purposefully selected for this study. Transitivity analysis as an analytical tool has been applied for the analysis of such the articles. By applying Halliday's transitivity system, hence; the study attempts to show how the use of linguistic signals can demonstrate the characteristics and techniques used in Pakistani print media for representing CPEC. Further, this study is comparative in nature, and compares the language used in both the English newspapers for representing CPEC. The findings indicate that CPEC has been presented as an economical subject of national worth in both the newspapers that implies a meaning of PRO-CPEC ideology. The current study is the significant in its originality as it is interdisciplinary study, and its findings are not in line with the exist in literature on media conflict.
\end{abstract}

Keywords: Critical Discourse Analysis; Transitivity; CPEC; English Newspapers

\section{Introduction}

However, a hot debate prevails in Pakistan regarding the freedom of media; it is out of question that ideology is constructed through such media. The Prime Minister - Imran Khan on his visit to America spoke with confidence as; "Pakistani media, in my opinion, is freer than the British media" (ANI, July.23, 2019). The statement implies a meaning of freedom of media in Pakistan irrespective to this; it is also thought that the state controls media. The PML-N spokesperson -Maryam Aurengzeb, asserted that the media is under bars of the current government and the news get censored and- are banned from publishing on account of personal capacity (BBC News, Jan.19, 2019). The differences of the thought related to media freedom clearly indicates that media plays a significant role in constructing an ideology.

${ }^{1}$ Institute of English Language and Literature, University of Sindh; and National University of Modern Languages (NUML) Karachi, Pakistan.

${ }^{2}$ Institute of English Language and Literature, University of Sindh, Jamshoro, Pakistan.

*)Corresponding Author.

Email: aekhteyar@numl.edu.pk 
During a visit to the Quetta Press Club, Balochistan Finance Minister- Mir Zahoor Ahmed Buledi, described the media as the state's fourth pillar (e.g., Express Tribune, 2020). Media is not only meant to spread news rather it presents the news in a desired way that shapes the mind of the people. The idea was supported by Rafique (2013), "When engaging with one another through foreign policy, the media forms public sentiment about liking or disliking any state or states". Reviewing literature of mass media discloses that media gives shape to the public thought. The desired ideologies are spread in the name of providing news to the public. In relation to the meaning or idea conveyed through media- makes a connection between media and language. Media is interconnected with the critical discourse analysis, and there is found a plethora on the role of media and the emerging field of critical discourse analysis (CDA). The discursive features as reflected in the media discourse constructs an ideology. Fairclough (2006a), stated that media discourse has ideological constructions that vary in their constructions. Such the variation in ideology leads to investigate deeply the discourse of mass media.

The context behind this research is provided by the news representation of a mega project in Pakistan i.e., China Pakistan Economic Corridor (CPEC) by the different newspapers. CPEC has gained a significant worth economically in Pakistan, however; the different views exist in the society related to CPEC. The purpose of the current study is to trace out the discursive features used in news articles dealing with the subject CPEC in Pakistani English newspapers.

CPEC is considered as first-rate economical phenomenon in Pakistan as it is exposed to public (Hamid \& Hameed, 2016). The terms like "Game changer", "Economic Boon", "Asian Tiger" have been employed while discussing CPEC (Dawn, 2016). The opponents of CPEC bring CPEC under surveillance and make it a centre of disruption due to its nitty-gritty and vitality. To begin with the domestic impediments, the greatest incipient threat is the truancy of law and order regulatory affairs. However, without security systemization and protocol, the intended benefits of the CPEC receive a blow as investors restrain from becoming a part of it. Thus, CPEC is under questions to which common masses are unaware of the reality. The current study aims at investigating the ideologies wrapped up in a discourse of media that are presented to public.

Hassan (1984), stated that the greatest obstacle for linguistics as a discipline is that the world of meanings is interpreted by social subjects as always being there; and the basic problem is to begin to demonstrate that meanings are objects, not provided by default, despite the fact that we grow up with them always around us (cited in Ammara, Anjum, and Javed, 2019). To translate what is being said, language is a social phenomenon. In the Ideational role of language, transitivity analysis is very useful for understanding the text's experiential meanings in a logical manner. Transitivity is thought to be a valuable framework for investigating how language constructs ideologies, themes, and definitions. It is a crucial system for interpreting human 
experience. This study may be useful for language researchers, stylisticians, discourse analysts and media concerned ones who are analyzing and interpreting the written texts from various literary genres and the discourse. The study opens up new avenues for researchers to explore discourse and style in different genres of literature using corpus-based methodologies.

\subsection{Critical Discourse Analysis: It's Scope in Pakistan}

Critical discourse analysis is a tool and a methodology for analyzing language that is used in a specific context. This isn't just a text analysis; it's a study of language in relation to the social aspects and power structures that shape society. Fairclough (2001), viewed that CDA analyses text and interactions, but it does not begin with text and interactions, it all begins with social issues and problems. Social issues and social concerns have a huge impact on the discourse that is key to critical discourse analysis. There are three models of Critical Discourse Analysis out of which Fairclough model works the best to the current study on its socio-cultural aspect. The Fairclough Model is an important in many ways, including the fact that it allows the analyst to concentrate on the text's signifiers, precise linguistic collections, juxtapositioning, sequencing, and layout. Textual research is carried out using multifunctional theories of language, such as systematic-functional linguistics (Fairclough, 1992).

Critical discourse research has exploded in popularity in Pakistan in recent years. In the field of CDA, several studies have been performed (Alam et al., 2017; Gopang \& Bughio, 2015; Mahmood et al., 2014; and Bilal et al., 2012). These studies indicate the emergence of CDA as a research repository in Pakistan.

Critical discourse analysis aims at exploring the ideology hidden in the discourse used in a specific context. The ideologies are spread through media using the different discursive features by the editors. The attempts on analyzing these features may unmask the power or the influence of the ruling body. The different depiction of the same news item can be observed through Critical Discourse Analysis of newspapers' articles. The study by Lodhi and his colleagues (2019), entitled Textual and Rhetoric Analysis of English and Urdu News Headlines is an attempt to scrutinize the print media news headlines by comparing how the different newspapers depict the similar events in the different ways. The study indicates a difference in discursive features used in the different media. Similarly, Hayat and Juliana published a report in 2016, on the Taliban's Attack on Malala Yousuf Zai through Comparative Analysis of Pakistani English Newspaper Editorials. The analysis looked at how Malala Yousaf Zai was portrayed in four Pakistani English newspapers after her attempt of assassination by the Taliban. Malala Yousuf Zai was framed as innocent and as well an American agent in some articles. The different portrayal of Malala Yousuf Zai- is a sign of the different ideology of the different editors that can be unmasked through critical discourse analysis. 
Critical discourse analysis can also reveal the worth of the same news. Alam et al. conducted a study in 2017, to look at how the Pakistani print media dealt with the conflict issue. The issue was a nationalist conflict in Baluchistan that revolved around a dispute between the government and the judiciary. The Baluchistan dispute has received no coverage in Pakistan's mass media as per the findings. It was also discovered that Jang, as opposed to Dawn, emphasized the weakness of political and religious leadership more. In comparison to Dawn, Jang was seen presenting the role of the judiciary in Baluchistan in a more positive light. This study is another attempt to prove that linguistics features may affect the meaning of the news - projected in media. The current study aims at analyzing the ideational meaning decoded in a language used in English newspapers' articles exploring an ideology constructed for CPEC in Pakistan.

\subsection{Transitivity Analysis: Halliday SFL Tenets}

One of Halliday's three SFG tenets is transitivity and described as the reflection of world processes through formal grammatical components. Perez (2007), linked Grammar to the reality in transitivity (p. 68). It considers a paradigmatic view of language, in which choices are the crucial. Simpson (1993), defines "Transitivity refers to how meaning is expressed in the clause". He added, "transitivity demonstrates how speakers encode their mental image of truth in language and account for their experience of the world around them since it concerns the transmission of ideas; it is a part of language's ideational function" (p. 88). Decoding and encoding facets of fact and world experience boils down to answering the following questions: who exists in the text? What is going on, and when, where, and how is it going on? The response to those questions lies in the assessment of transitivity in relation to concepts such as "method," "participant," and "circumstance". Burton (1982), puts this process of transitivity analysis as, "to explain the scenario of "who does what to whom" (p.200).

Halliday (1981), clarifies Transitivity as the clause analysis expressing ideational meanings. In this regard, it comes in the domain of Fairclough model. Transitivity is the system of analyzing an ideational meaning of the text. In transitivity analysis, the linguistics structures are observed in three ways: The process (verbs), the participants (nouns), and the circumstances (prepositional phrases). The choice of verbs depends on the social, cultural, political, and ideological factors prevailing in a society that is explored through an analysis of transitivity (Mayr, 2008). Text producer chooses verbs as per his own choice of the process' demonstration. The process can be of an active category or the passive category. The category of process type also plays a role in implying meaning to the text in relation to hegemony. Journalists in news discourse do more than just cover the news; they can also communicate their tacit meaning by using the various terms and processes (Liu \& Jia, 2020).The method, participants, and circumstances are the three 
components that make up transitivity. As the below given a diagrammatic figure represents the situation:

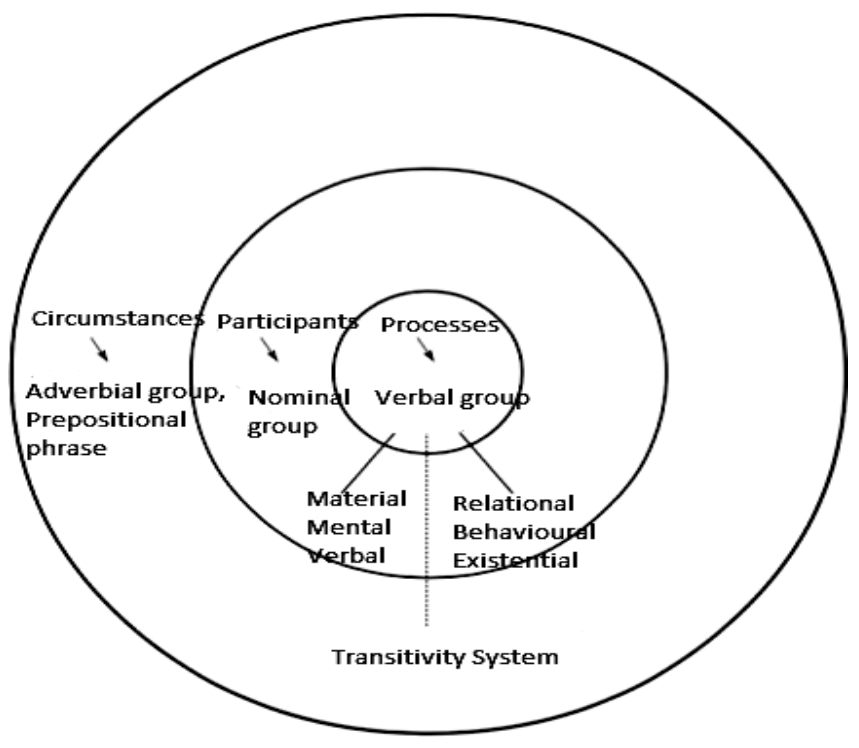

The verb is employed to interpret the process. The different roles of the participants have been depicted in the process types (Halliday, 1985). Table 1 depicted the various forms of processes, and their meanings as well the participants:

\begin{tabular}{lll}
\hline Types of Process & Categories of Meaning & $\begin{array}{l}\text { Functions of } \\
\text { Participant }\end{array}$ \\
\hline Material & $\begin{array}{l}\text { Act of Doing (go, come, } \\
\text { give) }\end{array}$ & $\begin{array}{l}\text { Actor, goal, } \\
\text { recipient, client }\end{array}$ \\
\hline Mental & $\begin{array}{l}\text { Experiencing, Sensing } \\
\text { (think, feel, seeing) }\end{array}$ & $\begin{array}{l}\text { Sensor, phenomenon } \\
\text { Verbal }\end{array}$ \\
$\begin{array}{l}\text { Act of Saying (said, tell, } \\
\text { argue) }\end{array}$ & $\begin{array}{l}\text { Sayer, verbiage, } \\
\text { receiver, Addressee }\end{array}$ \\
\hline Relational & $\begin{array}{l}\text { Being, becoming (be, } \\
\text { become, has, own) }\end{array}$ & $\begin{array}{l}\text { Carrier, Attribute, } \\
\text { Possessor, Possessed }\end{array}$ \\
\hline Behavioural & $\begin{array}{l}\text { Act of Behaving (laugh, } \\
\text { smiling, staring) }\end{array}$ & Behaviour \\
\hline Existential & Existing (there, exist, & Existent \\
\hline
\end{tabular}

Table1: Types of Process

\subsection{Research Questions}

RQ1: Which process type is found a leading one in the articles of English newspapers on the economical subject CPEC that construes a meaning? 
RQ2: How are an ideational meaning and CPEC ideology revealed through transitivity analysis of the articles in English newspapers?

\section{Research Methodology}

\subsection{Research Design}

The study follows the qualitative approach and descriptive in nature. However, the qualitative methodology focuses on debunking and constructing meaning by investigating and analyzing the meaning of phenomena and their social consequences that better suits to the current study.

Critical Discourse Analysis as a main theoretical framework of this study -has been chosen in order to examine news discourse critically. Under the domain of critical discourse analysis, Halliday SFL theory (1985), works at its optimum which sees the language as a meaning-making for which Ideational, interpersonal, and textual functions are three meta-functions. All languages are thought to have this ability to form and organize the meanings. The experiential and logical components of the ideational meta-function are separated, with transitivity allowing for further interpretation of the inner and outer world's experiences of human beings.

\subsection{Data Collection}

The articles have been purposefully selected from the leading English newspapers: Daily Dawn \& THE NEWS published during June 2016-June 2017. The ten articles were selected purposefully on the basis of selecting node of the study that is CPEC as a mega project.

\subsection{Data Analysis}

The analysis of process types (transitivity) has been made to construe the meaning in the text. The participants have also been analyzed to find out the role of CPEC projected by the editors in English newspapers

\subsection{Validity}

The importance of maintaining validity in a study- cannot be overstated. Critical discourse research has been subjected to a number of critiques, the most prominent of which is subjectivity. According to Widdowson (1995), 'CDA approach has been criticized for being too interpretive and subjective with no space for objectivity,'. Rich data used in the current study- invalidates the critique. The research is focused on a variety of data ranging from June 2016 to June 2017.

\subsection{Limitations of the Study}

The study is restricted to one meta- function namely, the ideational function of language. It can, however, be applied to other meta-functions as well. The analysis is limited to a single feature of ideational function known as transitivity. However, other aspects and characteristics of meta-functions may be studied. The articles have been chosen only from English newspapers. 
CPEC ideology in Pakistani print media can be observed in Urdu newspapers too.

\section{Results and Discussion}

The articles have gone through the analysis of process types. The process types that are reflected in the use of verbs - help in unveiling the ideology depicted by Pakistani English newspapers for CPEC. The analysis is depicted in the following table as;

Analysis of Process Types in English Newspapers

\begin{tabular}{|c|c|c|c|}
\hline \multicolumn{2}{|c|}{ Daily Dawn } & \multicolumn{2}{|l|}{ The News } \\
\hline Activity & Process Type & Activity & $\begin{array}{l}\text { Process } \\
\text { Type }\end{array}$ \\
\hline $\begin{array}{l}\text { CPEC is a new } \\
\text { cooperation framework }\end{array}$ & Relational & $\begin{array}{l}\text { CPEC is a project of } \\
\text { friendship }\end{array}$ & Relational \\
\hline is a game changer & Relational & CPEC is faster & Relational \\
\hline $\begin{array}{l}\text { it is also an important } \\
\text { project of the Belt and } \\
\text { Road initiative }\end{array}$ & Relational & $\begin{array}{l}\text { CPEC projects were } \\
\text { making steady progress }\end{array}$ & Material \\
\hline $\begin{array}{l}\text { Pakistan will } \\
\text { benefitted from it }\end{array}$ & Material & $\begin{array}{l}\text { it would contribute to } \\
\text { economic and social } \\
\text { development of Pakistan }\end{array}$ & Material \\
\hline $\begin{array}{l}\text { CPEC was a major } \\
\text { initiative }\end{array}$ & Relational & it would benefit people & Material \\
\hline $\begin{array}{l}\text { CPEC is a project of } \\
\begin{array}{ll}\text { development } \\
\text { prosperity }\end{array}\end{array}$ & Relational & & \\
\hline $\begin{array}{l}\text { CPEC would benefit } \\
\text { the entire region }\end{array}$ & Material & $\begin{array}{l}\text { It has brought a new } \\
\text { start to Pak-China } \\
\text { relation }\end{array}$ & Material \\
\hline 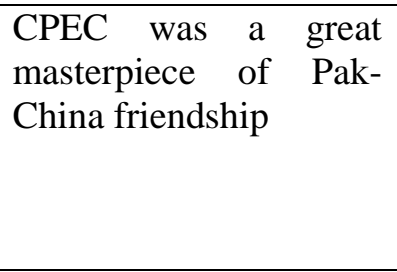 & Relational & $\begin{array}{l}\text { These projects will not } \\
\text { only change the face of } \\
\text { Karachi, but of the entire } \\
\text { province in terms of } \\
\text { transport facilities and } \\
\text { power generation }\end{array}$ & Material \\
\hline $\begin{array}{l}\text { CPEC will eliminate } \\
\text { poverty } \\
\text { unemployment }\end{array}$ & Material & $\begin{array}{l}\text { CPEC will benefit the } \\
\text { whole region from its } \\
\text { fruits. }\end{array}$ & Material \\
\hline $\begin{array}{l}\text { These projects would } \\
\text { ensure the elimination } \\
\text { of load shedding }\end{array}$ & Material & $\begin{array}{l}\text { CPEC would usher in a } \\
\text { new era of development } \\
\text { and prosperity in Khyber } \\
\text { Pakhtunkhwa }\end{array}$ & Material \\
\hline $\begin{array}{l}\text { CPEC would go on to } \\
\text { transform the fate of } \\
\text { the entire region }\end{array}$ & Material & $\begin{array}{l}\text { CPEC has opened new } \\
\text { vistas of foreign } \\
\text { investment in Pakistan }\end{array}$ & Material \\
\hline $\begin{array}{l}\text { CPEC is the way of } \\
\text { hope and future for our }\end{array}$ & Relational & $\begin{array}{l}\text { that CPEC project was } \\
\text { game changer and would }\end{array}$ & $\begin{array}{l}\text { Relational/ } \\
\text { Material }\end{array}$ \\
\hline
\end{tabular}




\begin{tabular}{|l|l|l|l|}
\hline region & & $\begin{array}{l}\text { bring good fortune to } \\
\text { Khyber Pakhtunkhwa }\end{array}$ & \\
\hline $\begin{array}{l}\text { It broadens our } \\
\text { technological } \\
\text { capabilities }\end{array}$ & Material & $\begin{array}{l}\text { The mega project would } \\
\text { turn and } \\
\text { Pakhtunkhwarial } \\
\text { Afghanistan into } \\
\text { economic centers for the } \\
\text { Central Asian countries }\end{array}$ & Material \\
\hline $\begin{array}{l}\text { CPEC raises friendship } \\
\text { to newer heights }\end{array}$ & Material & $\begin{array}{l}\text { CPEC is the path of } \\
\text { progress }\end{array}$ & Relational \\
\hline $\begin{array}{l}\text { the project envisioned } \\
\text { bringing under- } \\
\text { developed areas into } \\
\text { the main stream of } \\
\text { development }\end{array}$ & Material & $\begin{array}{l}\text { the CPEC would also } \\
\text { play a role in alleviating } \\
\text { poverty as well as } \\
\text { elimination of terrorism } \\
\text { and fanaticism }\end{array}$ & Material \\
\hline $\begin{array}{l}\text { CPEC would help in } \\
\text { establishing strong } \\
\text { academic linkages } \\
\text { between } \\
\text { universities of Pakistan } \\
\text { and China }\end{array}$ & Material & $\begin{array}{l}\text { the outcomes of this } \\
\text { project will enhance } \\
\text { regional cooperation }\end{array}$ & Material \\
\hline $\begin{array}{l}\text { project would not only } \\
\text { generate thousands of } \\
\text { jobs but also help in } \\
\text { generating thousands of } \\
\text { megawatts power }\end{array}$ & Material & $\begin{array}{l}\text { CPEC is a great gift of } \\
\text { Chinese leadership for } \\
\text { Pakistan }\end{array}$ & Relational \\
\hline
\end{tabular}

Table 2: Analysis of Process Types in Pakistani English Newspapers Dealing with the subject CPEC

\subsection{Transitivity Analysis}

The selected articles have undergone through the transitivity analysis. Their interpretation is described as the below; for instance:

\begin{tabular}{|l|l|l|l|}
\hline CPEC & is & a game changer \\
\hline Participant & Process & Participant & \multicolumn{2}{|l|}{} \\
\hline Carrier & Relational: Attribute & Attribute & \\
\hline
\end{tabular}

Source: Daily Dawn

\begin{tabular}{|l|l|l|l|}
\hline CPEC & is & $\begin{array}{l}\text { an important project of the Belt and Road } \\
\text { initiative }\end{array}$ \\
\hline Participant & Process & Participant & \\
\hline Carrier & Relational: Attribute & Attribute \\
\hline
\end{tabular}

Source: Daily Dawn

\begin{tabular}{|l|l|l|}
\hline CPEC & is & $\begin{array}{l}\text { an important project of Belt and Road } \\
\text { initiative }\end{array}$ \\
\hline Participant & Process & Participant \\
\hline
\end{tabular}




\begin{tabular}{|l|l|l|l|}
\hline Carrier & Relational: Attribute & Attribute & \\
\hline
\end{tabular}

Source: Daily Dawn

\begin{tabular}{|l|l|l|r|}
\hline CPEC & is & A way of hope and future & for our region \\
\hline Participant & Process & Participant & Beneficiary \\
\hline Carrier & Relational: Attribute & Attribute & \\
\hline
\end{tabular}

Source: Daily Dawn

\begin{tabular}{|l|l|l|l|}
\hline CPEC & is & $\begin{array}{l}\text { a great masterpiece of Pak-China } \\
\text { relationship }\end{array}$ \\
\hline Participant & Process & Participant & \\
\hline Carrier & Relational: Attribute & Attribute & \\
\hline
\end{tabular}

Source: Daily Dawn

Here, Relational process is presented through the state verb 'is' and attributing aspect of the subject is reflected in the word choice of 'game changer', 'an important project', 'way of hope', 'a great masterpiece of PakChina relationship' for the subject CPEC.

Similarly;

\begin{tabular}{|l|l|l|}
\hline CPEC & is & a mega project \\
\hline Participant & Process & Phenomenon \\
\hline Carrier & Relational: Attribute & Attribute \\
\hline
\end{tabular}

Source: The News

\begin{tabular}{|l|l|l|l|}
\hline CPEC & & is not only the & billion dollar investment \\
\hline Participant & & Process & Phenomenon \\
\hline Carrier & & Relational: Attribute & Attribute \\
\hline but & it & is & the path of progress \\
\hline & Participant & Process & Phenomenon \\
\hline & Carrier & Relational: Attribute & Attribute \\
\hline
\end{tabular}

Source: The News

\begin{tabular}{|l|l|l|}
\hline CPEC & is & a project of friendship \\
\hline Participant & Process & Phenomenon \\
\hline Carrier & Relational: Attribute & Attribute \\
\hline
\end{tabular}

Source: The News

\begin{tabular}{|l|l|l|}
\hline CPEC & is & faster \\
\hline Participant & Process & Phenomenon \\
\hline Carrier & Relational: Attribute & Attribute \\
\hline
\end{tabular}

Source: The News

Here, the Relational process is presented through the state verb 'is' and attributing aspect of the subject is reflected in the word choice of 'the billion dollar investment', 'the path of progress', 'project of friendship', 'faster' for 
the subject CPEC.

Relational process clauses are used to describe and classify the having and being process as observed in the above examples. This procedure creates a similarity relationship between two entities. It specifies the manner, time, and place of the entity. It symbolizes the ownership of one entity by another (Halliday, 2014). In the all above examples, the attributing aspects associated with the carrier 'CPEC' imply a positive meaning of CPEC.

The other leading process type is found Material process. Material process is used to highlight the actions usually the concrete ones. Actions representation includes 'actor' and 'goal'. Active categorization of the process type has been observed while talking about CPEC in the selected newspapers. CPEC as an active agent in almost all above example implies a meaning that Pakistani English newspapers deal CPEC project as an entity active enough to bring changes in Pakistan's future. For instance;

\begin{tabular}{|l|l|l|l|}
\hline CPEC & Raises & friendship & to newer heights \\
\hline Participant & Process & & \\
\hline Actor & Material & Goal & \\
\hline
\end{tabular}

Source: Daily Dawn

\begin{tabular}{|l|l|l|l|}
\hline It (CPEC) & broadens & $\begin{array}{l}\text { our technical } \\
\text { capabilities }\end{array}$ & \\
\hline Participant & Process & & \\
\hline Actor & Material & Goal & \\
\hline
\end{tabular}

Source: Daily Dawn

\begin{tabular}{|l|l|l|l|}
\hline CPEC & Raises & friendship & to newer heights \\
\hline Participant & Process & & \\
\hline Actor & Material & Goal & \\
\hline
\end{tabular}

Source: Daily Dawn

\begin{tabular}{|l|l|l|l|}
\hline CPEC & will eliminate & $\begin{array}{l}\text { poverty \& } \\
\text { unemployment }\end{array}$ & \\
\hline Participant & Process & & \\
\hline Actor & Material & Goal & \\
\hline
\end{tabular}

Source: Daily Dawn

\begin{tabular}{|l|l|l|l|}
\hline CPEC & $\begin{array}{l}\text { would } \\
\text { benefit }\end{array}$ & the entire region & \\
\hline Participant & Process & & \\
\hline Actor & Material & Goal & \\
\hline
\end{tabular}

Source: Daily Dawn

In the above examples of extracts from Daily Dawn ; CPEC is found an actor and material process as shown through the verbs 'would not only 
generate and would help', 'raises', 'will eliminate', 'would benefit for the goals 'thousands of jobs and thousands of megawatts', 'friendship', 'poverty and unemployment', and 'the entire region' respectively.

Similarly;

\begin{tabular}{|l|l|l|l|}
\hline CPEC & would play & $\begin{array}{l}\text { a role in } \\
\text { alleviating poverty }\end{array}$ & \\
\hline Participant & Process & & \\
\hline Actor & Material & Goal & \\
\hline
\end{tabular}

Source: The News

\begin{tabular}{|l|l|l|l|}
\hline CPEC & has opened & $\begin{array}{l}\text { new vistas of } \\
\text { foreign investment }\end{array}$ & in Pakistan \\
\hline Participant & Process & & \\
\hline Actor & Material & Goal & \\
\hline
\end{tabular}

Source: The News

\begin{tabular}{|l|l|l|l|}
\hline CPEC & $\begin{array}{l}\text { would } \\
\text { contribute }\end{array}$ & $\begin{array}{l}\text { To social and } \\
\text { economic } \\
\text { development }\end{array}$ & \\
\hline Participant & Process & & \\
\hline Actor & Material & Goal & \\
\hline
\end{tabular}

Source: The News

\begin{tabular}{|l|l|l|l|}
\hline CPEC & has taken & $\begin{array}{l}\text { a new start to Pak- } \\
\text { China relationship }\end{array}$ & \\
\hline Participant & Process & & \\
\hline Actor & Material & Goal & \\
\hline
\end{tabular}

Source: The News

CPEC as an active agent is presented in the above examples with the material process shown in the verb 'would play', 'has opened', 'would contribute', and 'has taken a new start' for the goal 'role in alleviating poverty', 'new vistas of foreign investment', 'socio-economic development ', and 'a new start to Pak-China relationship' respectively. The actor, according to Halliday (2014), execute the different roles and functions in association with the material process to reflect the physical world interactions, acts, and behaviours such as going, sitting, taking, giving, and so on. An 'actor' is someone who performs an action in a clause, whereas a 'goal' is something that is influenced by a verb in a clause. 'Actor' acts as a subject, while 'goal' acts as an object. Fairclough (2000), argued that while analyzing text, one important thing to analyze is to see where who acts. CPEC though is not an animate but, has been presented as an active agent in both the newspapers. The active category used for presenting CPEC presents CPEC being the beneficial for Pakistan. 
Mental process refers to the act of 'sensing,' which is divided into three categories: perception, affection, and cognition. Mental process was found rarely used in newspapers' articles for presenting CPEC in Daily Dawn and it was not found at all in THE NEWS newspaper. The illustration can be seen as;

\begin{tabular}{|l|l|l|l|}
\hline $\begin{array}{l}\text { The year } \\
\text { (2016) }\end{array}$ & also saw & $\begin{array}{l}\text { the financial impact } \\
\text { of the force }\end{array}$ & \\
\hline Participant & Process & & \\
\hline Sensor & Mental & Phenomenon & \\
\hline
\end{tabular}

Source: Daily Dawn

The verb 'saw' is an example of Mental Perception. This verb is used here by the writer with an intention to present CPEC as an economic growth. The ideology of PRO-CPEC is being constructed over here through portraying the year 2016, financially progressing.

CPEC is presented in English Pakistani newspapers as a lucrative one that will give the profit to Pakistan in different forms. CPEC is found in the all above examples playing a role of the participants 'Carrier' with the positive attributes in Relational process, and an 'Actor' with healthy goals in Material process. The findings of the study indicate that the transitivity system can effectively analyze text. In the study of reality representation, transitivity is a special term. It allows us to look at and represent the same situation and event in a variety of ways. Via transitivity research, the reader will learn about the thoughts of personas and determine "who does what to whom," that helps us in understanding the text (Halliday, 2014). The process types and the role of participant in a text unveil the ideology hidden in the text. below;

To conclude, the major findings come out of the analysis are described

- The material process has been observed frequently used in both the English newspapers

- The Relational process ranked second in presenting CPEC in both the English newspapers

- $\mathrm{CPEC}$ has been presented in the active structures in both the English newspapers playing the role of Carrier and Actor.

- Mental Process is not observed in THE NEWS and rarely observed in Daily Dawn representing CPEC

- The overall Pro-CPEC ideology has been observed in both the English newspapers

\section{Conclusion}

Transitivity is a significant semantic concept in the analysis of depiction of reality. Further, it assists us to unmask the reality hidden in the drapery of language specifically in media.

The study concludes that English newspapers in Pakistan have been found projecting the news on CPEC with the similar ideology i.e., PRO-CPEC. 
CPEC is an economical phenomenon of national concern so the subject has been reported with similar ideology and similar discursive features in both the leading newspapers of Pakistan. In both the English newspapers, CPEC has been presented as an active entity. Mey (2006), remarked Passivization as a matter of ideological concern in the media discourse. The active representation of a subject CPEC in both the English newspapers makes its worth evident in Pakistan. It is noteworthy point to add in the literature through the current study that English newspapers do construct the same ideology for the subject of CPEC as an economical phenomenon of national concern.

\subsection{Future Implications}

The future attempts may be made on Pakistani print media analysis selecting a political news item in the newspapers' articles. Thus, such a study may be distinct through implementing the different analytical tools.

\section{References}

Alam, R., \& Jullandhary, S. (2019). Coverage of Baluchistan Issues in leading Newspapers of Pakistan. Journal of Media Studies, 32(2).

Ammara, U. E., Anjum, R. Y., \& Javed, M. (2019). A Corpus-Based Halliday's Transitivity Analysis of'To the Lighthouse'. Linguistics and Literature Review, 5(2), 139-161.

Bilal, H. A., Rafaqat, U., Hassan, N., Mansoor, H., \& Zahra, Q. (2012). Editorials of Pakistani English print media: Application of CDA. International Journal of Linguistics, 4(3), 744-754.

Burton, D. (1982). Through glass darkly: Through dark glasses. In Carter. R (ed). (1982) Language and Literature: An Introductory Reader in Stylistics. London: Allen and Unwin.

Bustam, M. R. (2011). Analyzing clause by Halliday's transitivity system. Journal Ilmu Sastra, 6(1), 22-34.

Fairclough, N. (2013). Critical discourse analysis: The critical study of language. Routledge.

Fairclough, N. (2006). Semiosis, ideology and mediation: A dialectical view. In I. Lassen, J. Strunck, \& T. Vestergaard (Eds.), Discourse approaches to politics, society and culture. Mediating ideology in text and image: Ten critical studies (p. 19-35). John Benjamins Publishing Company. https://doi.org/10.1075/dapsac.18.04fai

Fairclough, N. (2003). Analysing discourse: Textual analysis for social research. Psychology Press.

Fairclough, N. \& Wodak, R. (1997). Critical discourse analysis. Discourse studies: Multidisciplinary introduction, 2, 258-284.

Fairclough, N. (1995). Critical discourse analysis: The critical study of language. London: Longman.

Ghannam, N. (2011). Newspaper ideology: A critical discourse analysis of an event published in six Lebanese newspapers 
Gopang, I. B., \& Bughio, F. A. (2017). Pakistani Budget 2013-2014: A Critical Discourse Analysis. International Journal of English language teaching, 2(1), 40-46

Halliday, M.A.K. (1981). Explorations in the Function of Language. London: Edward Arnold.

Halliday, M.A.K. (1985a). An Introduction to Functional Linguistics. London: Edward Arnold.

Halliday, M.A.K. (1985b). An Introduction to Functional Grammar. London: Edward Arnold.

Hameed, H. (2016). Pakistan's print media presentation of Pakistan China relation and new Silk Route corridor project (A Case Study of Chinese President Xi Jinping Visit Days). Journal of Political Sciences \& Public Affairs.

Hayat, N., \& Juliana, A. W. (2016). A Comparative Analysis of Pakistani English Newspaper Editorials: The Case of Taliban's Attack on Malala Yousafzai. Pertanika Journal of Social Sciences \& Humanities, 24(3).

Khan, I., Farooq, S., \& Gul, S. (2016). China-Pakistan Economic Corridor: News Discourse Analysis of Indian Print Media. Journal of Political Studies, 23(1).

Liu, Y. \& Jia, W. (2020). Critical Analysis and Identity Construction of Chinese News Media from Transitivity Perspective. International Education Studies, 13(1), 84-88.

Lodhi, M. A., Mukhtar, S., Akhtar, S., Nafees, K., Akhtar, N., \& Sajid, H. M. (2019). Textual and Rhetoric Analysis of News Headlines of Urdu and English Newspapers. International Journal of English Linguistics, 9(1), 324-342.

Mahmood, T., Kausar, G., \& Khan, G. Z. (2018). A Critical discourse analysis of the editorials of "Dawn" and "The New York Times" in the aftermath of Army Public School attack. The "Us" versus "Them" ideology. Journal of Research in Social Sciences (JRSS), 6(2), 1-17.

Mahmood, R., Obaid, M., \& Shakir, A. (2014). A Critical Discourse Analysis of figurative language in Pakistani English newspapers. International Journal of Linguistics, 6(3), 210.

Mey, J. (2009) Concise Encyclopedia of PRAGMATICS. $2^{\text {nd }}$ ed. London: Elsevier Ltd.

Perez. M. C. (2007). Transitivity in Translating, the Interdependence of Texture and Context. Bern: Peter Lang AG.

Rafique, M. (2013). US Image in the Pakistani Print Media: A Case Study of Pre and Post Abbottabad Operation. NDU JOURNAL, XXVII, 20730926.

Richardson, J. (2006). Analysing newspapers: An approach from critical discourse analysis. Palgrave.

Simpson, P. (1993). Language, ideology and point of view. New York: Routledge. 